\title{
Strategic Logic of Elite Purges in Dictatorships
}

Jun Sudduth, University of Strathclyde School of Government and Public Policy 


\title{
Strategic Logic of Elite Purges in Dictatorships
}

\begin{abstract}
Why do some leaders eliminate rivals from authoritarian regimes and therefore diminish elites' capabilities to remove them via coups, while others do not? By examining both dictators' incentives and opportunities to weaken regime elites, I show that dictators are more likely to eliminate rivals when elites' capabilities to oust dictators via coup is temporarily low. Thus, somewhat paradoxically, my theory predicts that dictators are more likely to weaken elites' capabilities as the threat of coup decreases rather than when coup risk is high. Furthermore, I argue that successful coups that put new dictators in power temporarily diminish elites' capabilities to remove dictators and, thus, provide a window of opportunity for the dictators to take steps to consolidate power. Empirical results using a new dataset on purges of militaries from 1969 to 2003 provide strong evidence for my hypotheses.
\end{abstract}




\section{Introduction}

Though many authoritarian leaders face powerful domestic audiences composed of regime elites who are willing and able to remove leaders via coup, some dictators have successfully eliminated strong rivals so that they no longer face powerful audiences who can punish them for policy decisions (Geddes, 1999, 2003; Goemans, 2000). Why do some leaders eliminate rivals from the regime and diminish elites' capabilities to remove them via coups, while others do not? Previous studies have offered two types of explanations. One focuses on leaders' incentives to weaken elites' capabilities to organize a coup, and the other emphasizes the opportunities that allow the leaders to pursue such a strategy. Some scholars argue that those leaders who face a high threat of coups are more likely to eliminate strong elites in order to reduce their coup risk (e.g., Biddle \& Zirkle, 1996; Roessler, 2011). ${ }^{1}$ Although these studies properly capture when dictators need most to purge rivals, they ignore the possibility that leaders' efforts to weaken elites often prompt the elites to launch a counter-coup to replace the leaders before losing their abilities to conduct a coup. One might wonder why dictators who already face high threats of coup would be willing to risk causing a coup by purging rivals. Other scholars instead focus on the secrecy in autocracies as the primary opportunity that allows dictators to weaken elites (e.g., Svolik, 2009). ${ }^{2}$ They argue that authoritarian leaders can diminish the elites' capabilities when their effort to do so goes unnoticed. Yet, dictators' actions to eliminate rival elites are typically well-witnessed by other regime insiders (Roessler, 2011).

Given that dictators' efforts to undermine elites' capabilities are typically not secretive, under what conditions do dictators eliminate rival elites without causing a counter-coup? Though existing theories are true in part, they are nevertheless incomplete because they have focused exclusively either on a dictator's need to weaken regime elites or on secrecy as a primary opportunity that allows him to do so. In this article, based on a formal model, I develop an argument that dictators are both willing and able to eliminate their rivals when the probability

\footnotetext{
${ }^{1}$ The term coup d'etat refers to an attempt by regime elites to remove political leaders using unconstitutional means -typically via the threat or use of force. Thus, elites who have access to physical forces (i.e. military officers) have central roles in organizing coups.

${ }^{2}$ I will use the terms autocratic, authoritarian, and dictatorial interchangeably, although some scholars attribute more specific meanings to each term.
} 
that elites can successfully remove the dictator via coup is temporarily low. When the elites' capabilities to oust the dictator are temporarily low, elites will tolerate a dictator's elimination tactics and wait until they recover their capabilities, rather than immediately stage a coup that is likely to fail. Knowing this, dictators need to take advantage of current opportunities in order to address the future risks of coup. Therefore, somewhat paradoxically, my theory predicts that dictators will diminish elites' coup-making capabilities as the threat of coup replacement decreases, challenging a conventional argument that dictators' efforts to weaken elites increase as coup risk increases.

In evaluating this theoretical implication, I focus on the role of successful coups in temporarily diminishing elites' capabilities to coordinate removing the dictator and consequently giving a window of opportunity for the dictator to eliminate elites. Specifically, immediately after a new dictator comes to power via coup, the number of elites who would be willing to challenge the new dictator via coup becomes temporarily small. Thus, the coup-entry dictator, upon coming to power, is able to dismiss rival elites including those individuals who put him in power. ${ }^{3}$ Importantly, this finding challenges existing claims that new leaders, on coming to power, face higher threats of coup and therefore exclude rival groups to reduce their coup risk (e.g., Roessler, 2011).

To test my theoretical claims, I use an original dataset of military purges for all 438 political leaders in 111 authoritarian countries from 1969 to 2003. Focusing on those elites that have access to physical forces - officers in the military or other security apparatus and civilian elites that are at the top of the security apparatus, I collected information about the timing of elite elimination using a variety of news sources. The use of this new data allows us to identify whether a dictator replaces, dismisses, or demotes rival military officers in a specific year and also identifies the ranks of the eliminated officers. Empirical results using this new data on purges of militaries provide strong evidence for my hypotheses.

This paper offers important contributions to several literatures. First, this paper improves our understanding of authoritarian politics by analyzing when authoritarian leaders make steps

\footnotetext{
${ }^{3}$ Throughout this article, I use the term a coup-entry leader to refer to a political leader who comes to power via coup and a coup-entry event to denote a successful coup that puts a new leader in power.
} 
toward becoming personalist dictators. Scholars argue that personalist dictatorships, where dictators have successfully eliminated strong elites over time so that the elite audiences are no longer able to hold the dictators accountable (Geddes, 1999), tend to be more conflict-prone and more dangerous to the international society than other types of regimes (Weeks, 2008, 2012). Though the literature recognizes the importance of personalization in autocracies, we know very little about the timing of when dictators actually promote the process of personalization of the regime. Second, though we have a large number of studies on repression that examine political authorities' actions to inhibit citizens' capabilities to challenge the authorities (e.g., Ritter, 2014; Conrad, 2011), less attention has been paid to leaders' actions to repress regime elites (especially militaries) that are key forces in carrying out state repression of citizens. This paper contributes to these literatures by developing a theory of elite elimination and introducing a new dataset of military purges which will help academics and policy makers begin to systematically understand leader-elite relations in autocracies.

\section{Dictators' Incentive and Opportunity to Weaken Elites}

Autocratic leaders eliminate potential rivals from the regime to undermine elites' capabilities to punish the leaders via coup (e.g., Geddes, 2003; Svolik, 2012). Elite elimination is defined here as dictators' actions to dismiss, replace, purge, or demote individuals from key positions who demonstrate high levels of ability and ambition. These positions are typically taken by the leaders themselves or individuals who are personally loyal to or uncritical of the leaders (Haber, 2006; Quinlivan, 1999; Egorov \& Sonin, 2011).

There are two types of existing studies that speak to the question of when authoritarian leaders eliminate rival elites from the regime. One line of research focuses on the dictator's incentives to reduce elites' punishment capabilities and the other focuses on the opportunities that allow him to do so. First, a large number of scholars argue that a political leader who faces high threats of coups imposed by strong elites is more likely to attempt to diminish the elites' coup-making capabilities. As the likelihood that the military and other elites will attempt a 
coup increases, the dictator is more inclined to diminish their capabilities to organize a coup by purging strong and competent officers (e.g., Stepan, 1971; Horowitz, 1985; Finer, 1988; Pollack, 1996; Belkin \& Schofer, 2003, 2005; Pilster \& Bohmelt, 2011). In other words, a dictator who faces a high coup risk tends to employ "coup-proofing" strategies in the form of purges and political replacement of military officers and other elites to reduce his coup risk (Biddle \& Zirkle, 1996; Quinlivan, 1999; Roessler, 2011).

Although these scholars have correctly captured when a dictator most needs to diminish elites' capabilities to replace him, they have not taken into account how elites, as strategic actors, will react to the dictator's effort to do so. Specifically, scholars have underestimated the possibility that the leader's actions to eliminate rivals would prompt elites to launch a countercoup to replace the leader immediately before they lose their abilities to conduct a coup. For example, in Uganda, President Obote attempted to undermine his army commander in chief, Idi Amin, but Amin was able to maintain the support of the majority of the army and responded by ousting Obote in a military coup in 1971 (Lentz III, 1994, pg. 775-776). In 1999 in Pakistan, just hours after Prime Minister Sharif dismissed powerful army chief Gen. Pervez Musharraf, Sharif was replaced by a coup led by Musharraf and his supporters in the military. Similarly, in Guinea Bissau, President Vieira dismissed the military chief of staff Ansumane Mané in 1998, which in turn caused Mané and his supporters in the military to promptly rebel against Vieira (IRIN, 1998). Given the military's reactions in these cases, one might wonder why a dictator would risk causing a coup by eliminating strong rival elites when he already faces a high probability of coup replacement.

A second line of research has instead focused on a dictator's opportunities to reduce elites' capabilities and claimed that the secrecy of authoritarian politics is the key behind power struggles between a dictator and elites (Svolik, 2009, 2012; Boix \& Svolik, 2013; Myerson, 2008). Specifically, scholars argue that a dictator is able to diminish elites' capabilities when his effort to do so goes unnoticed (e.g., Svolik, 2009, pg. 480).

The assumption of secrecy, however, does not always match with the process of elite purges in dictatorships. Although secrecy might pervade some aspects of authoritarian politics, 
a dictator's actions to eliminate his rival elites from key positions are typically well-witnessed by other regime insiders. ${ }^{4}$ Studying elite eliminations in sub-Saharan Africa, Roessler characterized them as public demotions and removals (Roessler, 2011, pg. 312). Indeed, an important purpose of purges of rival elites is to label the rivals as "the losing horse" and scare off other elites that are potentially disloyal to the dictator (Roessler, 2011, pg. 312). Rather than hiding purges of disloyal officers, Saddam Hussein, for example, typically announced the names of those officers who were suspected of disloyalty and they would be executed in front of all of their colleagues (Hirsh, 1991). Similarly, when Kim Jong-un dismissed his powerful uncle, Chang Song-Thaek, he chose to do so in front of a party meeting (BBC, 2013). By focusing on secrecy as a primary opportunity, the existing studies fail to account for the significant number of important cases in which dictators successfully eliminate their rivals when their actions are observable.

The above discussion illuminates an important puzzle: Given that dictators' efforts to reduce elites' capabilities are typically not secretive, under what conditions do dictators eliminate their rivals without prompting a coup? Although existing theories are true in part, they are nevertheless incomplete mainly because they have focused exclusively either on a dictator's need to weaken regime elites or on secrecy as a primary opportunity that allows him to do so. In the next section, I will present a formal model to analyze why a dictator might choose to undermine elites' capabilities even when the elites could observe his effort to do so (i.e. under complete information).

\footnotetext{
${ }^{4}$ Certainly, elite elimination can go unnoticed by elites in some cases and it is important to emphasize that my approach should not be seen as discounting the role of secrecy in explaining these cases. Rather, my theoretical approach tries to illuminate the key features of a strategic environment that may allow dictators to weaken elites even when their actions are observable.
} 


\section{Theory}

\section{Formal Model}

I present a two-period game between a dictator (D) and an elite (E) under complete information. The elite is defined as a group of individual elites in key positions that have legitimate access to the use of armed force and have an organizational interest in maintaining their capabilities to collectively punish the leader. The sequence of moves is as follows. The game starts in period 1 with D deciding whether or not and how much to weaken E's punishment capabilities by eliminating them. That is, $\mathrm{D}$ chooses an elimination effort, $c \in[0, \infty)$. The higher the level of elimination effort $c$, the more damaging the effect on E's future capabilities. D pays a cost $k>0$ in period 1 should he choose $c>0$. $k$ captures the cost of activities that D undertakes in order to effectively remove rivals from key positions. After observing D's elimination effort, E will respond by either launching a coup immediately, or by keeping the status quo. If E chooses the status quo, the game proceeds to period 2 and D's elimination effort becomes effective. If $\mathrm{E}$ decides to launch a coup, the coup will succeed with probability $p_{1}$ or will fail with probability $1-p_{1}$, and the game ends. $p_{1}$ reflects E's capability to successfully coordinate challenging D via coup in period 1 . If $\mathrm{E}$ successfully ousts $\mathrm{D}, \mathrm{E}$ will obtain $\pi$ and $\mathrm{D}$ will get zero, or vice versa in case of failed coups. By assumption, $\pi<1$ reflecting that the use of force is inefficient.

Period 2 begins with D choosing how to allocate the political or economic resources to E. D makes an offer $x \in[0,1]$ to $\mathrm{E}$ and $\mathrm{E}$ will decide whether to accept the offer, or to reject and stage a coup. If $\mathrm{E}$ accepts the offer, the game ends with $\mathrm{D}$ receiving $1-x$ and $\mathrm{E}$ obtaining $x$. If $\mathrm{E}$ decides to reject the offer, the coup succeeds and $\mathrm{D}$ loses power with probability $\frac{p_{2}}{1+c}$ or fails with $1-\frac{p_{2}}{1+c} . \quad p_{2}$ is E's baseline capabilities in period 2 and it might differ from $p_{1}$ reflecting temporal shifts in E's capabilities due to factors other than D's elimination efforts. ${ }^{5}$ For instance, changes in a country's economic performance or threats from outside the regime would produce temporal variation in the probability that elites successfully remove the dictator.

\footnotetext{
${ }^{5}$ In other words, elites' punishment capabilities can be temporarily low (or high) in period 1 and recover (or decline) in period 2 exogenously.
} 
If the coup succeeds, $\mathrm{D}$ gets zero and $\mathrm{E}$ gets $\pi$, and vice versa if the coup fails.

D's elimination effort is modeled as having a delayed effect which diminishes E's coupmaking capability and improves D's bargaining leverage in the future (period 2). ${ }^{6}$ This assumption that D's opportunistic actions do not have an immediate effect on E's capabilities to organize coups is common in the literature this article seeks to engage (e.g., Svolik, 2009, 2012). Immediately after dismissals, those dismissed officers can still have critical influences on their supporters in the regime and the elite as a group can keep the same level of capabilities to move against the leader. ${ }^{7}$ Once a certain amount of time has passed, though, newly appointed officers loyal to the leader start effectively exerting influence over and monitoring individuals in the regime, and the dismissed officers and their supporters will find it more difficult to challenge the leader. Certainly, killing a large number of elites could have an immediate effect on elites' collective capabilities. Yet these cases are very rare (Haber, 2006, pg. 699-700). Furthermore, for a large-scale violent purge to be successfully executed, a leader needs to have members of coercive institutions, such as the secret police or law enforcement agencies, completely under his control. Thus a dictator who can organize large-scale purges is considered to have already consolidated enough power by repeatedly eliminating his rivals and securing positions for him and his loyal followers over time. My theoretical focus in this article, instead, is the timing of when a political leader who takes power as the first among equals makes steps toward strengthening his position vis-a-vis rival elites through the gradual elimination of rivals.

In sum, the timing of the game is as follows.

\section{- Period 1}

\footnotetext{
${ }^{6}$ Though the substantive contexts differ widely, Debs \& Monteiro (2014) model the similar strategic interaction between two states where a target state makes decisions to invest in military capabilities that will shift the balance of power in its favor in the future, and its adversary decides whether to launch preventive war to preclude the power shift from occurring. My model differs from Debs and Monteiro in that I allow the power shifts to be not only endogenous (resulting from D's elimination efforts) but also exogenous.

${ }^{7}$ Pakistan's 1999 coup, for instance, corroborates this point. Prime Minister Sharif dismissed a powerful army chief Gen. Pervaiz Musharraf precisely when Musharraf was outside the country and it was more difficult for Musharraf and his supporters to effectively react to the dismissal. His supporters in the army, however, refused to follow the orders of newly appointed army chief Ziauddin Butt and managed to organize a coup against Sharif very quickly before Butt could take effective control of the army. Within 17 hours after the announcement of the dismissal, the army took over all key state buildings throughout the country, arrested Nawaz Sharif and Ziauddin Butt, and announced that Sharif has been dismissed (BBC, 2007).
} 
1. A dictator, $\mathrm{D}$, chooses elimination effort $c \in[0, \infty)$.

2. An elite, E, either launches a coup or keeps the status quo.

- If E stages a coup, the coup will succeed with probability $p_{1}$ or will fail with probability $1-p_{1}$, and the game ends.

- If E does not stage a coup, then the game continues to period 2.

- Period 2

1. D makes an offer $x \in[0,1]$ to E.

2. E either accepts the offer or stages a coup.

- If $\mathrm{E}$ accepts the offer, then the game ends with $x$ as the final allocation of resources to $\mathrm{E}$.

- If $\mathrm{E}$ rejects the offer, the coup succeeds with probability $\frac{p_{2}}{1+c}$ or fails with $1-$ $\frac{p_{2}}{1+c}$, and the game ends.

\section{Equilibrium Analysis}

The game has a unique pure strategy Subgame Perfect Equilibrium. I will first provide a formal statement of equilibrium behavior, followed by an intuitive discussion of why the equilibrium holds. Proofs of the propositions can be found in the Supplementary Appendix.

Proposition 1. The following strategies constitute the Subgame Perfect Equilibrium:

- Dictator

$$
\begin{aligned}
& c^{*}=\left\{\begin{array}{l}
\frac{p_{2}}{p_{1}}-1 \text { when } p_{1} \leq p_{2} \text { and } k \leq \pi\left(p_{2}-p_{1}\right) ; \\
0 \text { otherwise }
\end{array}\right. \\
& x^{*}=\left\{\begin{array}{l}
p_{1} \pi \text { when } p_{1} \leq p_{2} \text { and } k \leq \pi\left(p_{2}-p_{1}\right) ; \\
p_{2} \pi \text { otherwise }
\end{array}\right.
\end{aligned}
$$




$$
\begin{gathered}
\text { Coup }\left\{\begin{array}{l}
\text { choose status quo when } p_{1} \leq p_{2} \text { and } c \leq c^{\prime} \text {, where } c^{\prime} \equiv \frac{p_{2}}{p_{1}}-1 ; \\
\text { stage a counter-coup otherwise }
\end{array}\right. \\
\text { Bargaining }\left\{\begin{array}{l}
\text { accept when } x \geq x^{\prime}, \text { where } x^{\prime} \equiv p_{1} \pi \text { if } p_{1} \leq p_{2} \text { and } k \leq \pi\left(p_{2}-p_{1}\right), \\
\text { reject otherwise }
\end{array} \quad \text { and } x^{\prime} \equiv p_{2} \pi \text { if } p_{1}>p_{2} \text { or } k>\pi\left(p_{2}-p_{1}\right) ;\right.
\end{gathered}
$$

D's elimination effort is a double-edged sword. It is (i) a risky strategy in the short-term as it might prompt E to immediately launch a coup, although (ii) it is beneficial in the longerterm as it will diminish E's punishment capabilities in the future. The longer-term benefit of the elimination effort is captured by the bargaining stage in period 2. Recall that the game reaches period 2 if E decides not to foil D's elimination effort in period 1. In period 2, D needs to offer enough resources that $\mathrm{E}$ will accept in order to avoid a costly coup outcome. E will accept the amount of resources that are at least equivalent to what E expects to get from launching a coup. $\mathrm{D}$ has no incentive to offer more than the minimum $\mathrm{E}$ will accept, proposing $x^{*}=\frac{\pi p_{2}}{1+c}$ and reaching a bargain in equilibrium. Thus, the higher the level of elimination effort D chooses in period 1, the better bargaining outcome D can enjoy in period 2.

Although D's elimination effort would diminish E's coup-making capabilities in period 2 , it could be costly for $\mathrm{D}$ in the short-term as it might prompt a counter-coup. In period 1, after D chooses his elimination effort, E will decide whether to launch a coup or not by comparing the relative payoffs of each action. E's expected payoff from launching a coup is $p_{1} \pi$, while its expected payoff from choosing the status quo and moving to period 2 is $\frac{p_{2} \pi}{1+c}$. Thus, in deciding whether to launch a coup, E will essentially compare its capabilities to replace D in a current period $\left(p_{1}\right)$ with its anticipated capabilities to do so in the future $\left(\frac{p_{2}}{1+c}\right)$.

Any positive amount of elimination effort taken by $\mathrm{D}$ in period 1 will have a reductive effect on E's capabilities in period 2 ( $p_{2}$ vs. $\frac{p_{2}}{1+c}$ ). Yet if E's abilities to organize a successful coup in a current period $\left(p_{1}\right)$ are sufficiently lower than its future baseline capabilities $\left(p_{2}\right)$, 
the expected recovery in E's baseline capabilities could counteract the reductive effect of the elimination effort taken by D. Balancing these, $\mathrm{E}$ is better off not launching a counter-coup as long as D's elimination effort is equal to or less than $c^{\prime} \equiv \frac{p_{2}}{p_{1}}-1$. Once D's elimination effort becomes larger than the threshold of $c^{\prime}$, his effort to weaken $\mathrm{E}$ in period 1 is so damaging to E's future capability that E would have to try to immediately oust D. Knowing this, D will choose the maximum elimination effort $\mathrm{E}$ can tolerate $\left(c^{\prime}\right)$ in equilibrium. If, however, the cost of elimination effort $k$ is prohibitively high for $\mathrm{D}$ such that $k>\pi\left(p_{2}-p_{1}\right)$, D will be better off not making an elimination effort, choosing $c=0$ in equilibrium.

Once E's coup-making capability in period 1 becomes higher than its future baseline capability $\left(p_{1}>p_{2}\right)$, E will be better off resorting to a coup in period 1 even if $\mathrm{D}$ decides not to take elimination efforts. E's expected utility from choosing the status quo $\left(\frac{p_{2} \pi}{1+c}\right)$ is smaller than its expected utility from launching a counter-coup $\left(p_{1} \pi\right)$. Knowing that $\mathrm{D}$ will exploit its better bargaining position in period 2 once $\mathrm{D}$ becomes stronger, a temporarily strong $\mathrm{E}$ prefers to immediately launch a coup in period 1 when it has a temporal advantage. Recognizing this, D will choose $c=0$ in equilibrium avoiding the cost $k .^{8}$

\section{Implications}

The above argument has an important implication about the timing of when a dictator makes elimination efforts. It implies that a dictator eliminates rival elites and undermines their punishment capabilities when the elite's capabilities to organize a successful coup is temporarily low (i.e. $p_{1}<p_{2}$ ), provided the cost of elimination $k$ is not prohibitively high. ${ }^{9}$ This is because as long as the elite's capabilities in period 1 are lower than its expected baseline capabilities in period 2, a dictator can find some positive level of elimination effort that is small enough

\footnotetext{
${ }^{8}$ Allowing D to buy off a temporarily strong E in order to avoid a coup in a current period is a useful extension of my model. Note though that the literature has established that if the exogenous power shift is large and rapid, bargaining breaks down (in coups) in period 1 under complete information (e.g. R. Powell, 2004). Moreover, integrating a bargaining stage in period 1 would not alter the conclusions about D's choice of elimination effort. When D faces a temporarily strong E, D would still need to minimize its elimination effort $(c=0)$ in addition to offering enough resources to avoid a coup in period 1.

${ }^{9}$ This condition on $k$ (i.e. $k \leq \pi\left(p_{2}-p_{1}\right)$ ) implies that if D's actions to weaken $\mathrm{E}$ will not cause counter-coups, the benefit of such actions in reducing E's capabilities outweighs the cost of the actions. This assumption is shared by the literature (e.g., Svolik, 2009).
} 
for the elite to tolerate without launching a counter-coup in equilibrium. The elite prefers to tolerate a dictator's elimination effort and wait until it recovers its baseline coup-making capability rather than immediately launch a coup when the probability of a successful coup is low. The lower the elite's current punishment capabilities relative to its future capabilities, the higher amount of elimination effort the elite could tolerate without resorting to a coup. A dictator, therefore, needs to take advantage of the current opportunity of low risk of coup in order to prepare for the future risk of coup. Once the elite's capability to organize a successful coup in period 1 becomes higher than its baseline capability in period 2, a dictator would not make an elimination effort. A temporarily strong elite would launch a coup immediately rather than wait until it loses its temporal advantage. Foreseeing this, a dictator maximizes his utility by minimizing the cost related to an elimination effort and thus chooses not to engage in an elimination effort. In essence, a temporary weakness of an elite in terms of its capabilities to punish a dictator via coup will provide the dictator with a window of opportunity to promote the process of consolidation of power.

Implication 1. A dictator is more likely to make an elimination effort when the probability that an elite can successfully oust a dictator via coup is temporarily low. The lower the current probability that the elite can successfully oust the dictator relative to the future probability of coup replacement, the higher the levels of elimination effort the dictator will take.

The above analysis illuminates a new causal mechanism for elite elimination distinctly different from the existing literature's. First, in contrast to the existing work that exclusively focuses on a dictator's incentive to reduce an elite's punishment capabilities, my model expects that a dictator will increase the level of elimination efforts as the current threat of coups decreases. Second, scholars who focus on secrecy as a primary opportunity for elite elimination contend that a dictator would always be deterred from taking opportunistic actions when his actions were perfectly observable - i.e. no elite elimination efforts under complete information(Svolik, 2009, pg. 484). This view does not explain why some dictators choose to eliminate 
rivals even when their actions are perfectly observable.

Furthermore, my model differs from the existing models in that it acknowledges the possibility that a shift in an elite's punishment capability can result from factors other than a dictator's elimination effort, as captured by a possible difference in the values of $p_{1}$ and $p_{2}$. This point is essential in understanding why dictators are able to make elimination efforts under complete information. Though a dictator's elimination efforts will diminish an elite's capability, the elite's baseline capability in the future $\left(p_{2}\right)$ might be sufficiently higher than its current capability $\left(p_{1}\right)$ due to an exogenous capability shift. When an elite is temporarily weak $\left(p_{1}<p_{2}\right)$, the elite would prefer to tolerate a dictator's elimination effort without staging a coup as long as the expected recovery of its baseline capability ( $p_{1}$ vs. $p_{2}$ ) will counteract the reductive effect of elimination efforts on its capability ( $p_{2}$ vs. $\frac{p_{2}}{1+c}$ ). This is precisely the reason why a dictator is able to make an elimination effort without causing a coup even under complete information.

Whereas, for example in Svolik, the shift in the elite's capability is purely endogenous to a dictator's opportunistic behavior (Svolik, 2009, pp. 482). As a consequence, if there is any shift in the elite's punishment capability, it would always be in a negative direction such that elites will always become weaker in the next period due to a dictator's action to weaken them. This framework, thus, does not provide a good reason for why an elite would ever want to tolerate a dictator's opportunistic behaviors under complete information. If a shift in an elite capability is always in a negative direction, the elite would always prefer to launch a coup to prevent the dictator's opportunistic behaviors. This in turn would deter dictators' opportunistic actions under complete information.

\section{Empirical Analysis}

Assessing the validity of Implication 1 requires proper operationalization of the timing of changes in the probability that elites successfully overthrow a dictator - specifically, when the probability becomes temporarily low. In this section, I operationalize the temporary weakness 
of elites in two ways. One is to focus on the role of successful coups in temporarily reducing an elite's capabilities to remove a leader via coup and consequently allowing a leader to eliminate rivals. The other is to focus more generally on over-time variations of elites' coup-making capabilities and examine their impacts on elite eliminations. I restate Implication 1 in terms of these measurable concepts of temporary weakness of elites and translate it into hypotheses for empirical analyses.

\section{Hypotheses}

Ousting a dictator is a collective effort of a sufficiently large number of regime elites (Geddes, 2003). Whether a coup succeeds crucially depends on whether a large number of elites support the coup once it is launched (J. Powell \& Thyne, 2011). Specifically, a coup will succeed and a leader will be overthrown if a sufficient number of elites support the plot and challenge the leader, while the coup will fail if enough elites are loyal to the leader and do not support the coup attempt (Weingast, 1997; Geddes, 2003). Consequently, an individual elite's decision of whether to support a plot against a dictator crucially depends on his expectation about whether enough elites will participate in the plot to make the ouster successful (Nordlinger, 1977). The fundamental challenge facing an individual elite, though, is that it is not easy for him to draw an accurate inference about others' preferences. Since a dictator can retaliate against individuals for publicly expressing opposition to the dictator, individuals have incentives to conceal their preferences (Weeks, 2008). Thus, an individual elite generally has some level of uncertainty over both other elites' preferences and the probability that the coup will succeed.

This situation, however, can dramatically change under certain circumstances. The literature on mass protest activities provides us with great insight on this point (Lohmann, 1993, 1994; Kuran, 1989, 1991). Just as elites need to coordinate to punish a dictator, citizens under repressive regimes have to solve a coordination problem to overthrow a regime. People's incentives to take political action against the regime depend on their expectations about how many others will turn out and protest against the regime. Importantly, a mass political turnout in one time period is considered to influence the size of political turnout in the following period, as an 
individual modifies his beliefs about how many others oppose the regime based on the observed turnout numbers (Lohmann, 1994; Casper \& Tyson, 2014). Specifically, a mass protest activity at one time shows the number of people who are engaged in the protest, and this in turn changes each individual's expectation about others' actions in the following period (Kuran, 1991). In short, a large mass turnout will encourage other individuals to take political action against the regime in the future, whereas a low turnout will deter people from participating in a protest movement.

Applying this logic to a coordination problem among elites, I claim that successful coups that put a new dictator in power reveal that a sufficient number of elites capable of using violence are on the side of the new dictator and will in turn temporarily decrease the number of individual elites that would participate in a plot against the new leader. ${ }^{10}$ When a new dictator comes to power via coup, it effectively shows that a sufficient number of elites who are strong enough to oust the previous leader via violence are currently on the side of the new leader. Observing this, individual elites that were previously impartial or uncertain about others' preferences find it preferable not to challenge the new dictator as a coup attempt of this kind is most likely to fail. A coup entry event thus decreases the number of individuals who would be willing to coordinate against the new leader, and an elite's coup-making capability becomes sufficiently low just after a coup entry event.

Yet, the reductive effect of coup entry events on the probability that a sufficient number of elites will support a plot against a coup-entry dictator is only temporary and an elite will recover its coordination capabilities quickly. This is primarily because the more time that passes since a particular coup, the less accurate and less relevant does information obtained from the coup become, and thus the less likely are people to use the same coup event to infer others' (current) preferences. After a certain length of time has passed since a successful coup, people can no longer expect that the same number of elites who helped a dictator come to power would still be loyal to the dictator. Therefore, an individual elite will become less hesitant about participating in a plot against the dictator and over time more and more people become willing to challenge

\footnotetext{
${ }^{10}$ Similar logic can also apply to post-failed coup phases such that failed coups show the strength of incumbent leaders and temporarily diminish elites' punishment capabilities. I explore this point in Appendix G.
} 
the coup-entry dictator.

The above discussion indicates that an elite's capabilities to successfully overthrow a dictator become temporarily low immediately after a new leader comes to power via coup, as summarized in the following two hypotheses. It is important to acknowledge that the following two hypotheses are statements of conceptual assumptions that are required to operationalize and assess Implication 1, and are not theoretical claims derived from the formal model. In the following section, I will test these hypotheses to see whether the assumptions underlying my approach to operationalize the main theoretical implication find empirical support.

Hypothesis 1. A dictator who comes to power via coup enjoys a temporarily low risk of coup replacement at the beginning of his tenure.

Hypothesis 2. When a dictator comes to power via coup, he is less likely to be replaced by a coup than if he comes to power by other means. This negative effect of coup entry on the probability that a dictator is overthrown by a coup is strongest at the beginning of his tenure and declines over time.

Given that an elite becomes temporarily weak immediately after a new leader comes to power via coup, my theory predicts that coup-entry leaders, upon coming to power, are able to eliminate rival elites without fear of coup as eliminated officers and their supporters cannot find enough people to fight back. Those elites, including the leaders' original supporters, who are anxious about the new dictator's moves would prefer to tolerate and wait until the reductive effect of coup entry on the elite's coordination capabilities diminishes, rather than stage a counter-coup when the number of people willing to challenge the dictator is extremely small. Even if eliminated elites and their supporters choose to launch a coup, their attempt to topple the leader is most likely to fail as the majority of other elites would hesitate to join them immediately after a successful coup. In Sudan, for instance, a few months after Gaafar Nimeiry took power via coup in 1969 , he dismissed three officers from the Cabinet and military posts 
who were the original members of the Free Officers' Group that put him in power. This pushed one of the dismissed officers, Major el Atta, to organize a coup against Nimeiry but the coup failed as those forces loyal to Nimeiry and other officers who had refused to join Major el Atta's forces immediately fought back. All coup leaders including el Atta were quickly arrested and executed (Lentz III, 1994, pg. 710).

The above discussion predicts the following hypotheses about elite elimination.

Hypothesis 3. A dictator who comes to power via coup is more likely to eliminate rival elites from the regime at the beginning of his tenure and then becomes less likely to do so over time.

Hypothesis 4. When a dictator comes to power via coup, he is more likely to eliminate rival elites than if he comes to power by other means. This positive effect of coup entry on the probability that a dictator eliminates his elites is strongest at the beginning of his tenure and declines over time.

While the above discussion focuses on the roles of successful coups in temporarily reducing an elite's capabilities, an elite's capabilities to organize a coup could depend on various other factors as well. To take this into account, the following hypothesis focuses more generally on over-time variations in the probability of coup replacement to operationalize a temporary weakness of elites. As the probability that an elite can oust a dictator in a current period decreases relative to the level of coup threat a dictator typically experiences in a country, the elite becomes more likely to tolerate a dictator's elimination effort and wait until it recovers its capabilities in the future. The lower the elite's current punishment capabilities, the higher amount of elimination effort the elite could tolerate. A dictator, therefore, is more likely to engage in higher levels of elimination effort without fear of coup response. In short, my theory predicts that decreases in the current probability of coup replacement within countries will increase the likelihood that leaders engage in elite elimination.

Hypothesis 5. A dictator is more likely to eliminate rival elites as the current probability that an elite can successfully oust a dictator via a coup decreases. 


\section{Data and Model}

To test my hypotheses, I use data in time-series cross sectional format and with leader-year as the unit of analysis. To create my dataset, I first identified authoritarian regimes according to Cheibub et al. (2010). ${ }^{11}$ They define dictatorships as regimes in which governmental offices are not filled as a consequence of contested elections. The list of political leaders is obtained from Archigos (Goemans et al., 2009). Though the data on regime type has the country-year format, I identify the leader under whose leadership the regime transition occurred, consulting with several sources including the codebook on authoritarian leadership by Svolik \& Akcinaroglu (2007) and notes that were used to make the coding of Cheibub et al. (2010).

My main dependent variable in this study is whether dictators eliminate potentially disloyal elites from key positions of the regime. ${ }^{12}$ To create this variable, I collected an original dataset on elite elimination. To make the new dataset I gathered information from a variety of news sources, including the Keesing Record of World Events, Lexis-Nexis news searches and literature on individual countries. I collected information for all 438 political leaders in 111 authoritarian countries from 1969 to 2003. I dropped Afghanistan, North Korea, Mongolia, Lebanon, Comoros, Lesotho, Belarus, Cyprus, Bosnia and Helzegovina, and East Germany because I could not find sufficient information to accurately code for these countries. This gives us 111 authoritarian countries. Also the data currently goes back to the year 1969 since the relevant articles obtained from Lexis-Nexis news searches start in 1969.

I then coded these news articles following several guidelines. First, my coding focuses on eliminations of elites who have legitimate access to physical forces capable of violence. Although the initial stage of coup attempts frequently involves civilian elites alone, whether these civilian coup-plotters can successfully replace the incumbent leader crucially depends on whether they can gain (at least implicitly) support from the military or other security apparatus (J. Powell \& Thyne, 2011). Thus eliminations of elites that have access to physical forces -

\footnotetext{
${ }^{11}$ In Appendix F, I test all of my hypotheses using the data of authoritarian regimes measured by (i) Polity IV data (Marshall et al., 2014) and (ii) Geddes et al. (2014) data (GWF). The results are all consistent with the hypotheses.

${ }^{12}$ Due to space limitations, I discuss limitations of existing data on elite elimination in Appendix B.
} 
officers in the military or other security apparatus and civilian elites that are at the top of the security apparatus such as the defense minister or interior minister - are considered to be the most crucial in reducing the threat of coup replacement. Second, I had to distinguish incidents where dictators purge rival officers in order to diminish elites' coup-making capabilities, from incidents where dictators dismiss officers purely because of their incompetence or other nonpolitical reasons. To do so, I examined whether a dictator eliminates rival elites (i) who are popular among other elites and thus are suspected to be potential threats to his political survival, (ii) who have different policy preferences and criticize the dictator's policy, and (iii) who (are suspected to) have planned to overthrow the leader or the regime. ${ }^{13}$ If an incident meets one of these criteria, I consider the incident an act taken by the dictator to weaken elites' abilities to punish the dictator. ${ }^{14}$ Finally, purge incidents where coup-entry dictators punish those officers who clearly challenged the dictators during the coup are not coded as elite elimination in my data.

Following these criteria, I created two dichotomous variables measuring whether a dictator replaces, dismisses, or demotes rival elites who have legitimate access to coercive forces in a specific year. Purge $I$ is a dichotomous indicator of whether a dictator eliminates military officers according to the above criteria. Purge II captures a slightly narrower concept of elite elimination where a dictator's purge is targeted at those who helped put him in power. Specifically I created Purge II by excluding from Purge I those cases where a dictator eliminates military officers for being closely connected to the previous leader or the previous government. In my dataset, Purge I is coded as 1 for 320 leader-years and Purge II is coded as 1 for 303 leader-years out of all 3200 leader-year observations. ${ }^{15}$

\footnotetext{
${ }^{13}$ These three categories are not meant to be exclusive. The examples of (i) include Syria's President Hafez Assad's attempt to limit the influence of his brother, Rifaat al-Assad, by eliminating those high ranking officers loyal to Rifaat, or the purges by Albania's Enver Hoxha of those officers who were associated with Prime Minister Mehmet Shehu, who had shared power with Hoxha from the end of the World Word II. Regarding (ii), for instance, Algeria's President Chadli Benjedid dismissed high ranking officers including the army's military security chief. These officers were the most influential hard-liners opposing the President's economic liberalization policies in 1988. One example of (iii) is that Cameroon's President Paul Biya dismissed and arrested those officers who were considered to have planned a plot against the regime in 1983.

${ }^{14}$ In evaluating the nature of purges, I primarily relied on news sources' and the literature's accounts of purge events. I checked whether their accounts are backed by facts rather than being purely based on statements from the government/regimes.

${ }^{15}$ See Appendix B for more detailed descriptive statistics of the purge data.
} 
In addition, I created an ordered variable Purge Level to capture the levels of elimination effort. In general, higher-ranking officers are considered to take more crucial roles in organizing successful coups than lower-ranking officers because they have better access to key facilities and enjoy societal trust (Thompson, 1976). Thus, purges of higher-ranked officers would have more damaging and reductive effects on elites' future coup-making capabilities. Based on this logic, I created Purge Level which captures the ranks of eliminated officers. More precisely, Purge Level takes a value of 3 when a dictator purges military officers, including the highestranked officers such as the army chief of staff, chief of general staff, commander of the army (or navy or air force), or ministerial positions such as the defense minister or interior minister. It takes a value of 2 if the dictator purges mid-level officers, such as the commander of the regional command, army general and colonel generals, takes a 1 if he purges only soldiers, and takes a 0 if no purge occurred that year.

Coup Replacement is a dichotomous variable taking a value of one if a dictator loses office via coup in that year and zero otherwise. Coup Entry is a dichotomous variable indicating whether a dictator comes to power via coup. Specifically, Coup Entry is coded as one for a coup-entry dictator during the entire time of his tenure, while it is coded as zero for a dictator who comes to power by other means. The information on when coup attempts successfully replace incumbent dictators comes from J. Powell \& Thyne (2011). Since J. Powell \& Thyne (2011) have information on the exact date of coup d'etat but does not specify which leader is replaced by a coup, I consult with several sources such as Lentz III (1994) and Svolik \& Akcinaroglu (2007) to determine which dictator is overthrown by a coup in a specific year.

Tenure measures how many years have passed since a dictator took power. To test the conditional nature of my hypotheses, I use Coup Entry, the natural log of Tenure and their interaction terms Coup Entry $\times \log$ (Tenure) as independent variables. To choose the time dependency, I compared the model including Log(Tenure), the model with Tenure, and the model with time polynomials -Tenure, Tenure ${ }^{2}$, and Tenure ${ }^{3}$ - using likelihood ratio tests. The results of likelihood ratio tests consistently indicate that the model with the interactions between Coup Entry and Log(Tenure) has a better model fit than other specifications. 
In both models of Purges and Coup Replacement, I include several control variables. $\log (G D P / c a p i t a)$ and Change in GDP/capita - a year-to-year percentage change in GDP per capita - are included to capture the claim that good economic performance inhibits coup incidents (Londregan \& Poole, 1990). Data for these indicators come from Gleditsch (2002). Log(Military Expenditure) measures the log of the total military budget and captures the claim that an increase in the military's organizational resources reduces potential grievances among officers against a political leader (J. Powell, 2012). I obtain this data from the Correlates of War capability (CINC) components, Version 3.02 (Singer et al., 1972). To capture regime types of authoritarian governments, I use the data on monarchic, military and civilian dictatorships coded by Cheibub et al. (2010). Monarch and Military Dictator are dichotomous variables indicating whether the regime's decision makings rely on family and kin networks, or on the armed forces within juntas. A base category in my analyses is a civilian dictatorship. Although Cheibub et al. (2010) is a country-year dataset, I assign leaders to their appropriate regime type by consulting with historical sources and notes that were used to make their coding. Party is a dichotomous variable indicating whether there is at least one defacto party inside the regime. The information for this variable comes from Cheibub et al. (2010). Interstate War is a dichotomous variable indicating whether a country engaged in an interstate war in that year and is taken from version 4.0 of the War Data Collection compiled by the Correlates of War Project (Sarkees \& Wayman, 2010). This variable captures the idea that military officers are more united around the incumbent leader and are less likely to attempt a coup during war. At the same time, the pretense of war allows incumbent governments to realign the military around loyalists and exclude rival officers (Huntington, 1968). Failed Coup is a dichotomous variable indicating whether a dictator previously faced a failed coup during his tenure. In my model of Coup Replacement, I also include a dummy for Bolivia to reflect the fact that it is a country where a coup replacement of a dictator most frequently happens in my data.

Given that the data is time-series cross-sectional with binary and ordered dependent variables, I use both logit and ordered logit models to test my hypotheses. I employ robust standard errors clustered by country to take into account the potential heteroskedasticity of observations 
with a given country. To account for the duration dependency, I include Years after Purge which measures how many years have passed since the previous military purge by a given dictator, Years after Purges ${ }^{2}$ and Years after Purges ${ }^{3}$ following Carter \& Signorino (2010).

\section{Results}

I test predictions about two types of dependent variables. One is whether a dictator is replaced via coup in a given year (Coup Replacement). The other is whether a dictator eliminates rival elites from the regime in a given year (Purge). I will examine these two sets of hypotheses in turn.

\section{Coup Replacement}

I first test my hypotheses about coup replacements. Hypothesis 1 states that a coup-entry dictator enjoys a temporarily low risk of coup replacement at the beginning of his tenure. Hypothesis 2 posits that a coup-entry event has a reductive effect on the probability of coup replacement and this reductive effect is only temporary. Recall that these claims are about assumptions that are necessary to operationalize and assess my theoretical implication. I test the validity of these assumptions to see whether the subsequent approach to test Implication 1 is appropriate.

The results from five slightly different models using the Coup Replacement dependent variable are shown in Table 1. All five models in Table 1 have the key independent variables -Coup Entry, Coup Entry $\times \log ($ Tenure $)$ and $\log ($ Tenure $)$ - that allow us to test hypotheses 1 and

2. The results in Table 1 provide us considerable support for my hypotheses. As predicted by Hypotheses 2, a coup-entry incident has a negative impact on the probability that a dictator is successfully overthrown by a coup at the beginning of the dictator's tenure, i.e., the coefficient on Coup Entry is negative and significant in all five model specifications reported in Table 1. Also, as predicted, this negative effect of Coup Entry on the probability of coup replacement is strongest at the beginning of his tenure and declines over time, i.e., the coefficient on Coup Entry $\times \log ($ Tenure $)$ is positive and significant in all five model specifications reported in Table 1. 
To obtain more meaningful interpretations, I graphically illustrate the effect of Coup Entry and Tenure on the probability of coup replacement in Figure 1. First, in the left panel of Figure 1, I plot the predicted probability of coup replacement for both coup-entry and non coupentry dictators. The figure shows that dictators who come to power via coups face a temporarily low risk of being overthrown by coups at the beginning of their tenure. The probability that a coup-entry dictator is replaced by a coup is low at the beginning of his tenure but it quickly increases. This is exactly what Hypothesis 1 predicts. Upon coming to power, coup-entry dictators should enjoy a temporarily low risk of being removed by coups as a successful coup that puts the new dictator in power temporarily prevents elites from coordinating against the dictator. In contrast with coup-entry dictators, we see that non coup-entry dictators have a temporarily high risk of being replaced by coups at the beginning of their tenure.

Figure 1: Effect of Coup Entry and Tenure on the Probability of Coup Replacement
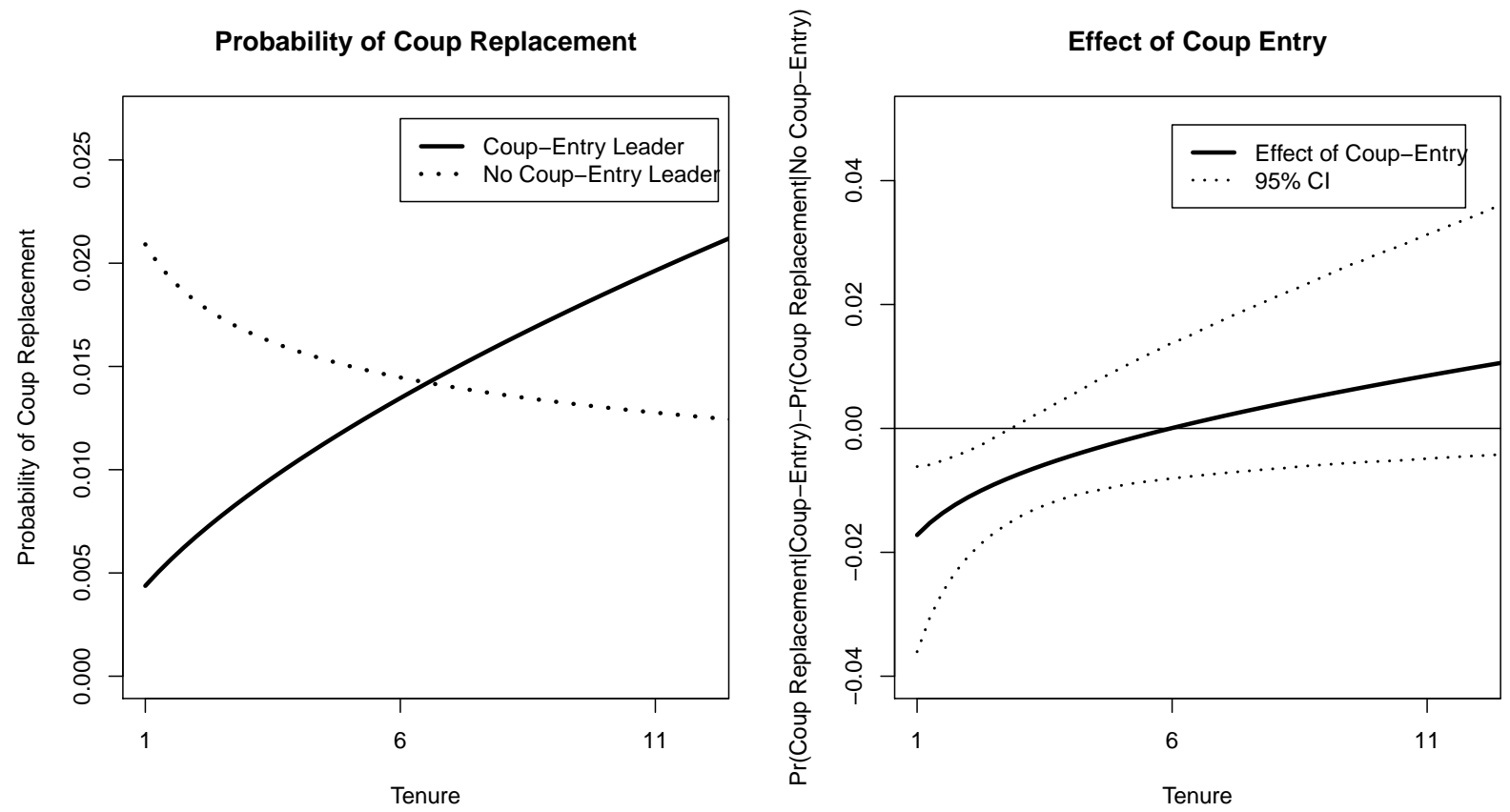

I also plot the effect of a coup entry event on the probability of coup replacement across

Tenure in the right panel of Figure 1. The effect of Coup Entry is calculated as the first difference, a change in the probability of coup replacement when we increase the variable Coup Entry from 0 to 1 holding the other variables at their means or medians. The solid sloping line 
in the figure indicates how the first difference for Coup Entry changes as Tenure increases.

The plot in the right panel of Figure 1 shows that a coup-entry event has a reductive and significant impact on the probability of coup replacement when dictators' tenures are smaller than 3. This reductive effect of Coup Entry, however, decreases as Tenure increases and Coup Entry stops having a significantly negative effect once Tenure becomes more than 3. Overall, the results indicate that a coup-entry event has a strong reductive effect on the probability of coup replacement at the beginning of a dictators' tenure, and this reductive effect is only temporary and declines over time. This is precisely what Hypothesis 2 expects.

In terms of the control variables, the evidence in Table 1 appears to be consistent with previous studies' findings. For example, the existence of political parties in an authoritarian regime is considered to have a reducing effect on a successful coup (Geddes, 2006) and this is supported by the negative and significant coefficients on Party in all five models in Table 1. Also the negative and statistically significant coefficient on $\log$ (Military Budget) in all five models in Table 1 implies that increases in a military's budget reduce the probability that leaders will be ousted via coup, which is in line with the literature (J. Powell, 2012).

\section{Military Purges}

In this section, I will assess my theoretical implications regarding the timing of military purges. Recall that Hypothesis 3 states that coup-entry dictators are more likely to eliminate elites at the beginning of their tenure. Hypothesis 4 claims that a coup-entry event will increase the probability that dictators eliminate elites and this positive impact of coup-entry will decline over time. To test these hypotheses, I estimate four slightly different models in Table 2. Models 1 and 2 use Purge I as the dependent variable, while Models 3 and 4 use Purge II which is a proxy for purges against dictators' original supporters. The results in Table 2 provide strong support for both hypotheses 3 and 4 . The results, for example, show that a coup-entry incident increases the probability of elite elimination. This is indicated by the positive and significant coefficient on Coup Entry in all four models. Also this positive effect of coup entry on the probability of military purges will decline over time. This can be seen by the negative and 
significant coefficient on Coup Entry $\times \log ($ Tenure $)$ in all four models.

Figure 2: Effect of Coup Entry and Tenure on Military Purges

Probability of Military Purge

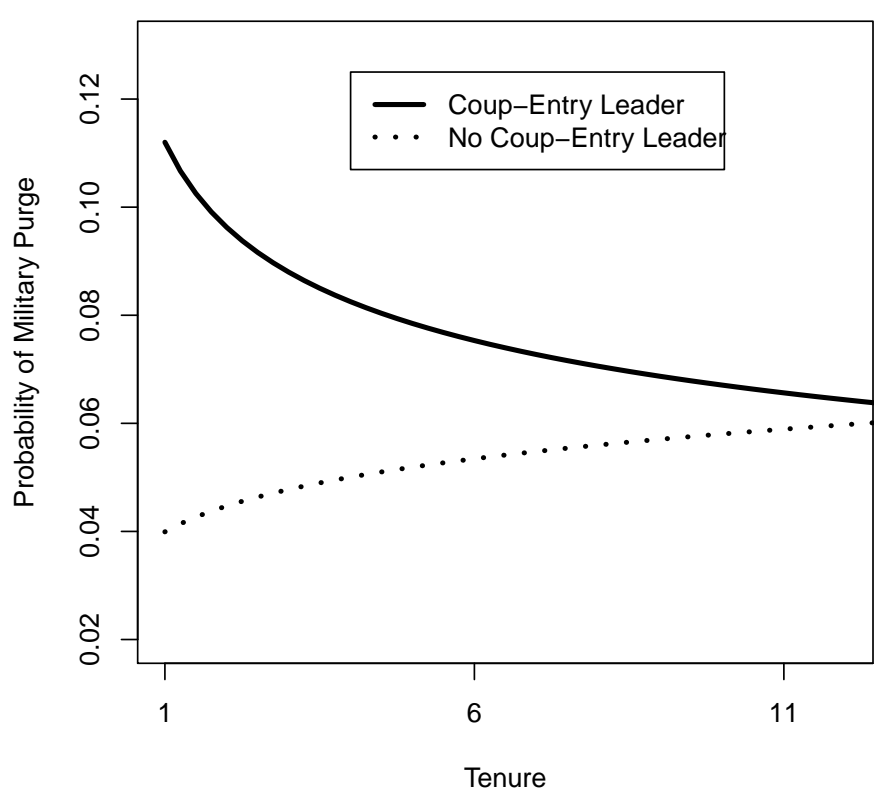

Effect of Coup Entry

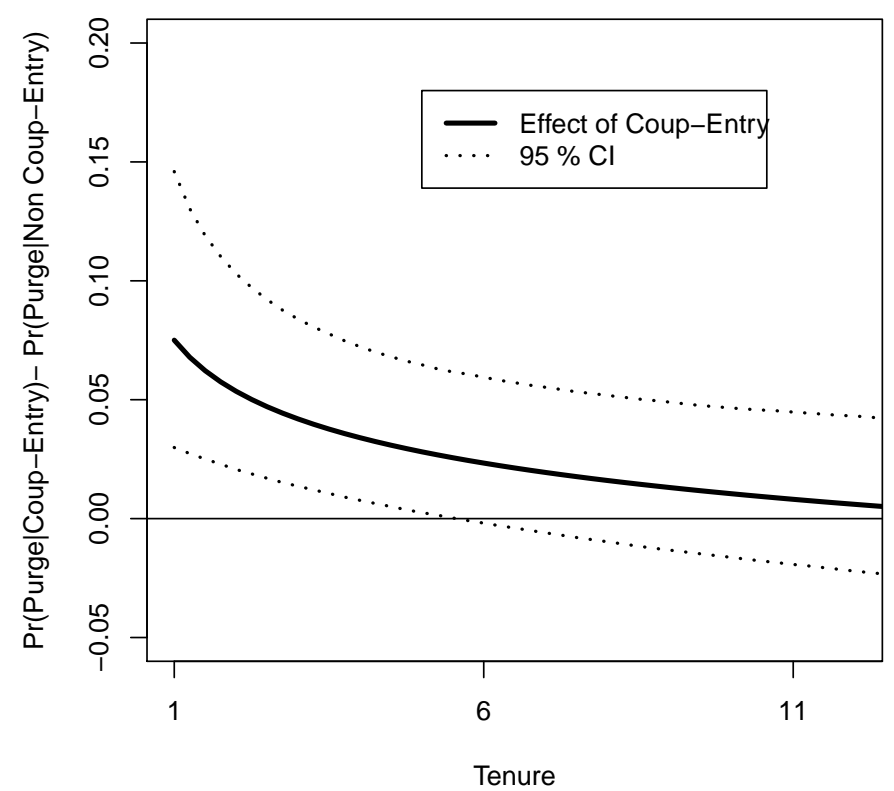

To further evaluate my hypotheses, I plot the effect of Coup Entry and Tenure on Purge in Figure 2. As predicted by Hypothesis 3, the left panel of Figure 2 shows that a coup-entry dictator is more likely to eliminate rival elites at the beginning of his tenure. As shown in Figure 1, a coup-entry dictator enjoys a temporarily low risk of coup replacement upon coming to power and, thus, he needs to take advantage of it and eliminate elites before elites recover their coordination capabilities. Figure 2 is consistent with my expectation. On the other hand, in Figure 1, we see that a non coup-entry dictator faces a temporarily high risk of being overthrown via coup at the beginning of his tenure. Combining my theory and this result, we should expect that non coup-entry dictators are less likely to purge the militaries at the beginning of their tenure as this kind of purge will most likely cause a countercoup and elites are strong enough at this point for the countercoup to succeed. Consistent with this expectation, the left panel of Figure 2 reveals that non coup-entry dictators are least likely to eliminate rivals just after they take power.

I also plot the effect of Coup Entry on the probability of military purge across the ob- 
served range of Tenure in the right panel of Figure 2. The effect of Coup Entry is calculated as the first difference, a change in the probability of military purges when we increase the variable Coup Entry from 0 to 1, holding the other variables at their means or medians. Consistent with Hypothesis 4, the right panel of Figure 2 shows that coup-entry dictators are significantly more likely to eliminate rival elites during the first few years of their tenure than non coup-entry dictators. Coup Entry has a positive and significant impact on military purges when Tenure is smaller than 6. This positive effect of Coup Entry declines as Tenure increases and Coup Entry stops having a significantly positive effect once Tenure becomes more than 6. Overall, Figure 2 provides us strong support for both hypotheses 3 and 4.

\section{Accounting for Alternative Explanations}

One criticism may be that my empirical findings are somewhat obvious as they might just show that new coup-entry leaders indeed punish those who opposed them during the coup or those who are loyal to the previous government overthrown by the coup. I will make a few points regarding this possible criticism. First, as I mentioned earlier, my purge variable does not include events where coup-entry dictators punish those individuals who fought against the dictators during the coups. Second, as seen in Table 2, my empirical inferences hold with the variable Purge II which excludes events where dictators eliminate individual elites for being closely connected to, or loyal to, the government overthrown by the coup. Most importantly, the empirical results presented here are in line with my theoretical reasoning of why coup-entry dictators eliminate elites, which differs from the existing argument. The existing literature claims that coup-entry leaders, upon coming to power, face higher threats of coups than others, as the way they took power gave rise to more enemies and, therefore, they have to eliminate those imminent threats (Roessler, 2011). My theoretical reasoning is distinct from the existing one in that I claim that a coup-entry event temporarily diminishes elites' capabilities to coordinate against the leader and, therefore, a coup-entry dictator can eliminate his potential threats. Figure 1 provides evidence consistent with my argument.

Other possible alternative explanations for the observed patterns might be that, first, a 
new leader must convince his supporters at the outset of his tenure that he will remain loyal to them by excluding other powerful elites in order to strengthen the loyalty norm (Bueno de Mesquita et al., 2003; Albertus \& Menaldo, 2012). This argument, however, cannot explain the different temporal patterns of purges for coup-entry and non coup-entry leaders shown in Figure 2. Specifically, if a new leader has incentives to stabilize the regime by building loyalty, how can we explain the finding that a non coup-entry leader is least likely to eliminate rivals at the onset of his tenure and becomes more likely to purge over time? Second, some might argue that an observed temporal pattern of military purge for coup-entry leaders might reflect that leaders who already have purged enough at the beginning of their tenure do not need to do so later and, hence, there is a declining trend in purge over time. To examine this possibility, I generate a variable Number of Past Purges which counts the total number of military purges a given leader has conducted in the past during his tenure. I include this variable in Models 2 and 4 in Table 2 and find it to be positive and significant. Hence, in contrast with the alternative explanation, the probability of military purges increases as the number of past purges increases. Importantly, the interpretation of our primary variables does not change upon the inclusion of Number of Past Purges. Finally some may contend that more eliminations occur during coup-entry leaders' tenures because those individuals who have confrontational personalities or abilities to organize violence select themselves into a group of coup-entry leaders and these individual-specific traits might explain the positive effect of Coup Entry on Purge. This argument, however, does not explain why the positive impact of Coup Entry is only temporary, rather than permanent.

\section{Coup Replacement and Military Purge}

I now evaluate the theoretical implication by using over-time variations in the probability of coup replacement within countries as a measure of a temporary weakness of elites. Specifically, Hypothesis 5 states that a dictator is more likely to eliminate rival elites as the current probability that an elite can successfully oust a dictator via a coup decreases. Following the approach by Zorn (2001), I measure within-country over-time variations in the probability of coup replacement by how much the current probability of coup replacement deviates from the 
country-medians of the probability of coup replacement. ${ }^{16}$ Specifically, using logit models of Coup Replacement in Table 1, I generate $\operatorname{Pr}(\text { Coup Replacement })_{i t}-\operatorname{Pr}(\text { Coup Replacement })_{\text {Med }}$ for each leader-year, where $\operatorname{Pr}(\text { Coup Replacement })_{i t}$ is the predicted probability that a dictator $i$ is removed via coup in a year $t$ and $\operatorname{Pr}(\text { Coup Replacement })_{M e d}$ is the (leader's) country's medians of the probability of coup replacement for the period 1969-2003. Thus this operationalization allows us to identify how much the current level of coup threat facing a leader temporarily deviates from the level of coup threat the leader typically experiences in a given country. Hypothesis 5 states that decreases in the current probability of coup replacement within countries will increase the likelihood that leaders engage in elimination tactics. In Table 3, $\operatorname{Pr}(\text { Coup Replacement })_{\text {Dev }}$ refers to how the deviations from the country-medians of $\operatorname{Pr}($ Coup Replacement) affect elimination effort.

I also include $\operatorname{Pr}(\text { Coup Replacement })_{M e d}$ to take into account how variations in median levels of coup threat across countries affect elimination effort (i.e., between-country effects). As the literature's claim that leaders with higher risk of coup tend to purge militaries might work at a between-country level, we need to simultaneously estimate within-country effects and between-country effects in the analyses (Zorn, 2001; Wright et al., 2015).

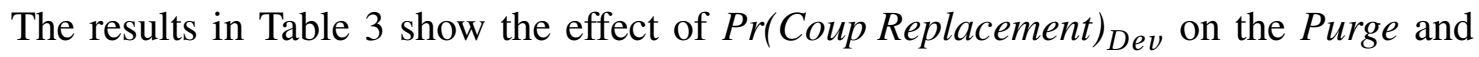

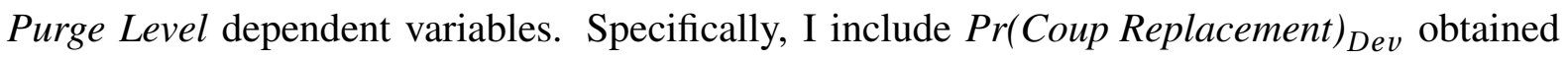
from the logit models in Models 1 and 2 in Table 1 as an independent variable in the logit models in Models 1 and 2 respectively in Table 3. Similarly, I add $\operatorname{Pr}(\text { Coup Replacement })_{\text {Dev }}$, estimated from the logit models in Models 1 and 2 in Table 1, as an independent variable to the ordered logit model in Models 3 and 4 respectively in Table 3. I control several variables that are expected to have an influence on military purges aside from any influences they might have on the likelihood of coup replacement. As this two stage approach will yield artificially deflated standard errors, I bootstrap standard errors. ${ }^{17}$

The results in Table 3 show that dictators are more likely to eliminate rival officers

\footnotetext{
${ }^{16}$ I use the country median, not the mean, because the mean tends to be heavily influenced by outliers and may not be a good representation of the centre of the data. Results, though, are similar and support Hypothesis 5 when we use the country mean of $\operatorname{Pr}$ (Coup Replacement). See Appendix D.

${ }^{17}$ See, for example, Beardsley (2010).
} 
when the current probability that elites can oust a leader via coup decreases relative to the country-medians. This can be seen by the negative and statistically significant coefficient on $\operatorname{Pr}(\text { Coup Replacement })_{D e v}$ in all four models shown in Table $3 .{ }^{18}$ Furthermore, the results of the ordered logit models in Table 3 show that a dictator is more likely to eliminate higher-ranked officers as the current probability of coup replacement diminishes relative to the

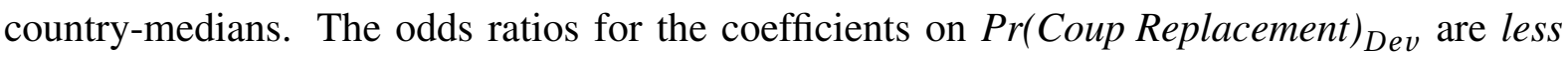
than one in both Models 3 and 4 reported in Table 3. Model 3, for example, shows that for one unit increase in $\operatorname{Pr}\left(\right.$ Coup Replacement $_{D e v}$, the odds of high-ranked officer purges versus the combined categories of middle-ranked officer purges, soldier purges and no purges are .0001 times smaller, given the other variables are held constant. Similarly, for a one unit increase in $\operatorname{Pr}(\text { Coup Replacement })_{D e v}$, the odds of the combined categories of high- and middle-ranked officer purges versus the combined categories of soldier purges and no purges are 0.0001 times smaller. In short, the lower the current probability of coup replacement within countries, the more likely a leader is to target higher-ranked officers as opposed to lower-ranked officers. These are consistent with my theoretical implication that decreases in the current probability of coup replacement increase the level of elimination effort dictators engage. Note also that the threshold parameters are significantly different from each other in both Models 3 and 4 in Table 3 and suggest that my ordered categories of the Purge Level variable are truly different from each other. Overall, the results in Table 3 provide us strong support for Hypothesis 5.

\section{Conclusion}

The theory and empirical results presented in this paper have several implications. First, this article deepened our understanding of authoritarian politics by exploring non cooperative survival strategies for political leaders. Many scholars examine how nominally democratic institutions, such as political parties (Geddes, 2008; Magaloni, 2008), elections (Magaloni, 2006; Blaydes, 2011) and legislatures (Gandhi, 2008; Gandhi \& Przeworski, 2007; Wright, 2008), promote

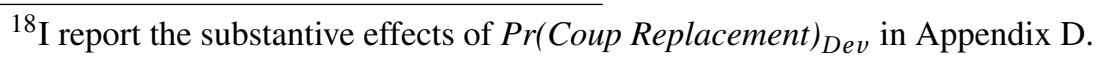


the survival of dictators. In particular, many point out that these nominally-democratic institutions protect authoritarian leaders from threats from within by allowing the leaders to co-opt elites and facilitate cooperation among them (Geddes, 2008; Magaloni, 2006, 2008; Blaydes, 2011). Surprisingly few studies, however, have studied why some dictators instead choose to weaken elites and accumulate power at the expense of elites. This article contributes to the literature on authoritarianism by providing a theoretical framework to identify the conditions under which dictators take such non-cooperative and non-power-sharing survival strategies rather than invest in political institutions. Furthermore, this article's findings shed some light on the effectiveness of political institutions. The literature suggests that institutions are effective in promoting power-sharing only when elites have abilities to punish leaders should the leaders renege on their promises to provide enough resources to elites (Boix \& Svolik, 2013). Combining the literature's claim and this article's finding thus suggests that a temporary weakness of elites caused by successful coups will eventually make authoritarian institutions ineffective and cause them to break down. Future research should further investigate how these different types of survival strategies - the cooperative approach based on political institutions and the non-cooperative approach based on purges and violence - influence each other and shape leader-elite relationships in autocracies.

Second, by introducing original data on elite elimination, this paper offers the first steps to empirically examine how authoritarian leaders take steps to consolidate power. The literature on authoritarian politics typically uses the data on personalist regimes originally created by Geddes (2003) as an indicator of whether a dictator has concentrated enough power at the expense of elites (e.g. Weeks, 2008, 2012). Yet, unfortunately Geddes's personalist variable is time invariant across the regime spell (Geddes et al., 2014). Specifically, those dictators who are considered to have eventually consolidated power are coded as personalist from the beginning of their tenure, which is inconsistent with the scholarly understanding of the consolidation of power (Svolik, 2012). A regime becomes personalized after a dictator has eliminated rival elites over time and this process is considered to take a long time (Svolik, 2009). By identifying when authoritarian leaders eliminate strong rivals, my data offers the first steps to empirically 
explore the process of concentration of power in autocracies. Future research will benefit from carefully studying the impact of repeated elite eliminations on dictators' survival and elites' capabilities to organize a successful coup.

Another question that needs further investigation would be how citizens might impact the power dynamics between leaders and elites in autocracies. Though this article exclusively focuses on the interactions between dictators and elites, the literature on coups suggests that citizens can indirectly influence the power balance between dictators and elites because plotters' abilities to successfully remove a dictator depend on public discontent with the incumbent leader and their willingness to condone or support a coup attempt. The public's perception is crucial for coups to succeed because tactically-successful coups can be overturned by widespread disapproval among the general public (e.g Galetovic \& Sanhueza, 2000). A successful coup requires most of the population to at least implicitly support and obey the coup plotters' commands. The implication of this view is that political leaders who are popular among citizens have more opportunities to eliminate elites as the elites have a low chance of successfully fighting back and ousting the leaders in this case. The problem for citizens, though, is that by supporting the incumbent leader, citizens might make the countries more vulnerable toward foreign threats. Once dictators successfully eliminate powerful elites to the extent that elites can no longer hold leaders accountable, the dictators will be more likely to initiate costly wars in a reckless manner (Weeks, 2012). Purging powerful and capable officers would also lower militaries' fighting abilities on the battlefield (Reiter \& Stam, 2002). Further studies to explore how citizens respond to the above trade-off and how political leaders would manipulate policies and boost the support of the public in order to weaken elites would be quite meaningful. 


\section{References}

Albertus, M., \& Menaldo, V. (2012). If You're Against Them You're With Us: The Effect of Expropriation on Autocratic Survival. Comparative Political Studies, 45(8), 973-1003.

BBC. (2007, August). How the 1999 Pakistan coup unfolded. BBC.

BBC. (2013, December). What is known about North Korea's brutal purge? BBC.

Beardsley, K. C. (2010). Pain, pressure and political cover: Explaining mediation incidence. Journal of Peace Research, 47(4), 395-406.

Belkin, A., \& Schofer, E. (2003). Toward a Structural Understanding of Coup Risk. Journal of Conflict Resolution, 47(5), 594-620.

Belkin, A., \& Schofer, E. (2005). Coup Risk, Counterbalancing, and International Conflict. Security Studies, 14(1), 140-177.

Biddle, S., \& Zirkle, R. (1996). Technology, Civil-Military Relations, and Warfare in the Developing World. The Journal of Strategic Studies, 19(2), 171-212.

Blaydes, L. (2011). Elections and Distributive Politics in Mubarak's Egypt. New York: Cambridge University Press.

Boix, C., \& Svolik, M. (2013). The Foundations of Limited Authoritarian Government: Institutions, Commitment, and Power-Sharing in Dictatorships. Journal of Politics, 75(2), 300-316.

Bueno de Mesquita, B., Smith, A., Siverson, R. M., \& Morrow, J. D. (2003). The Logic of Political Survival. Cambridge, MA: MIT Press.

Carter, D. B., \& Signorino, C. S. (2010). Back to the Future: Modeling Time Dependence in Binary Data. Political Analysis, 18, 271-292.

Casper, B. A., \& Tyson, S. A. (2014). Popular Protest and Elite Coordination in a Coup d'etat. Journal of Politics, 76(2), 548-564.

Cheibub, J. A., Gandhi, J., \& Vreeland, J. R. (2010). Democracy and Dictatorship Revisited. Public Choice, 143(1), 67-101.

Conrad, C. R. (2011). Constrained Concessions: Dictatorial Responses to Domestic Political Opposition. International Studies Quarterly, 55(4), 1167-87-614.

Debs, A., \& Monteiro, N. P. (2014). Known Unkonws: Power Shifts, Uncertainty, and War. International Organization, 68(1), 1-31.

Egorov, G., \& Sonin, K. (2011). Dictators and Their Viziers: Endogenizing the LoyaltyCompetence Trade-Off. Journal of the European Economic Association, 9.

Finer, S. (1988). The Man on Horseback: The Role of the Military in Politics. Boulder, CO: Westview. 
Galetovic, A., \& Sanhueza, R. (2000). Citizens, Autocrats, and Plotters: A Model and New Evidence on Coups D'etat. Economics and Politics, 12(2), 183-204.

Gandhi, J. (2008). Political Institutions under Dictatorship. New York, NY: Cambridge University Press.

Gandhi, J., \& Przeworski, A. (2007). Authoritarian Institutions and the Survival of Autocrats. Comparative Political Studies, 40(11), 1279-1301.

Geddes, B. (1999). What Do We Know about Democratization after Twenty Years. Annual Review of Political Science, 2, 115-44.

Geddes, B. (2003). Paradigms and Sand Castles. Theory Building and Research Design in Comparative Politics. Ann Arbor: The University of Michigan Press.

Geddes, B. (2006). Why Parties and Elections in Authoritarian Regimes? (Unpublished Manuscript, UCLA)

Geddes, B. (2008). Party Creation as an Autocratic Survival Strategy. (Unpublished Manuscript, UCLA)

Geddes, B., Wright, J., \& Frantz, E. (2014). Autocratic Breakdown and Regime Transitions: A New Data Set. Perspectives on Politics, 12(2), 313-31.

Gleditsch, K. (2002). Expanded trade and GDP data. Journal of Conflict Resolution, 46(5), 712-724.

Goemans, H. (2000). War and Punishment: The Causes of War Termination and the First World War. Princeton, NJ: Princeton University Press.

Goemans, H., Gleditsch, K. S., \& Chiozza, G. (2009). Introducing Archigos: A Data Set of Political Leader, 1875-2003. Journal of Peace Research, 46(2), 269-283.

Haber, S. (2006). Authoritarian government. In The oxford handbook of political economy (p. 693-707). Oxford, United Kingdom: Oxford University Press.

Hirsh, M. (1991, July 12). Saddam Said Purging Military, Inner Circle To Head Off Coup Bid. The Associated Press.

Horowitz, D. L. (1985). Ethnic Groups in Conflict. Berkeley: University of California Press.

Huntington, S. P. (1968). Political order in changing societies. Cambridge, MA: Harvard University Press.

IRIN, W. A. (1998). Fighting in capital continues. (African Studies Center, University of Pennsylvania)

Kuran, T. (1989). Sparks and Prairie Fires: A Theory of Unanticipated Political Revolution. Public Choice, 61(1), 41-74.

Kuran, T. (1991). Now Out of Never: The Element of Surprise in the East European Revolution of 1989. World Politics, 44(1), 7-48. 
Lentz III, H. M. (1994). Heads of States and Governments- A Worldwide Encyclopedia of Over 2,300 Leaders, 1945 through 1992. Jefferson, North Carolina, and London: McFarland and Company, Inc.

Lohmann, S. (1993). A Signaling Model of Informative and Manipulative Political Action. American Political Science Review, 87(2), 319-333.

Lohmann, S. (1994). The Dynamics of Informational Cascades: The Monday Demonstrations in Leipzig, East Germany, 1989-91. World Politics, 47(1), 42-101.

Londregan, J. B., \& Poole, K. T. (1990). Poverty, the Coup Trap, and the Seizure of Executive Power. World Politics, 42.

Magaloni, B. (2006). Voting for Autocracy; Hegemonic Party Survival and Its Demise in Mexico. Cambridge: Cambridge University Press.

Magaloni, B. (2008). Credible Power-Sharing and the Longevity of Authoritarian Rule. Comparative Political Studies, 41(4).

Marshall, M. G., Gurr, T. R., \& Jaggers, K. (2014). POLITY IV PROJECT: Political Regime Characteristics and Transitions,1800-2013. http://www.systemicpeace.org/inscr/p4manualv2015.pdf.

Myerson, R. B. (2008). The Autocrat's Credibility Problem and Foundations of the Constitutional State. American Political Science Review, 102(1), 125-139.

Nordlinger, E. (1977). Soldiers in Politics: Military Coups and Governments. New Jersey: Prentice-Hall, Inc. Englewood Cliffs.

Pilster, U. H., \& Bohmelt, T. (2011). Do Democracies Engage Less in Coup-Proofing? On the Relationship between Regime Type and Civil-Military Relations. Foreign Policy Analysis.

Pollack, K. M. (1996). The Influence of Arab Culture on Arab Military Effectiveness. (Ph.D. dissertation. Massachusetts Institute of Technology)

Powell, J. (2012). Determinants of the Attempting and Outcome of Coups d'etat. Journal of Conflict Resolution, 56(6), 1017-1040.

Powell, J., \& Thyne, C. (2011). Global Instances of Coups from 1950-2010: A New Dataset. Journal of Peace Research, 48(3).

Powell, R. (2004). The Inefficient Use of Power: Costly Conflict with Complete Information. American Political Science Review, 98(2), 231-241.

Quinlivan, J. T. (1999). Coup-proofing: Its Practice and Consequences in the Middle East. International Security, 24(2), 131-165.

Reiter, D., \& Stam, A. C. (2002). Democracies at War. Princeton and Oxford: Princeton University Press.

Ritter, E. H. (2014). Policy Disputes, Political Survival, and the Onset and Severity of State Repression. Journal of Conflict Resolution, 58(1), 143-168. 
Roessler, P. (2011). The Enemy Within: Personal Rule, Coups, and Civil War in Africa. World Politics, 63(2), 300-346.

Sarkees, M. R., \& Wayman, F. (2010). Resort to War: 1816 - 2007. Washington, DC.: CQ Press.

Singer, J. D., Bremer, S., \& Stuckey, J. (1972). Capability Distribution, Uncertainty, and Major Power War, 1820-1965. In B. Russett (Ed.), Peace, war, and numbers. Beverly Hills: Sage.

Stepan, A. (1971). The Military in Politics: Changing Patterns in Brazil. Princeton: Princeton University Press.

Svolik, M. W. (2009). Power Sharing and Leadership Dynamics in Authoritarian Regimes. American Journal of Political Science, 53(2), 477-494.

Svolik, M. W. (2012). The Politics of Authoritarian Rule. Cambridge: Cambridge University Press.

Svolik, M. W., \& Akcinaroglu, S. (2007). Government Change in Authoritarian Regimes Codebook. (Dataset)

Thompson, W. R. (1976). Organizational Cohesion and Military Coup Outcomes. Comparative Political Studies, 9(3), 255-276.

Weeks, J. L. (2008). Autocratic Audience Costs: Regime Type and Signaling Resolve. International Organization, 62, 35-64.

Weeks, J. L. (2012). Strongmen and Straw Men: Authoritarian Regimes and the Initiation of International Conflict. American Political Science Review, 106(2), 326-347.

Weingast, B. R. (1997). The Political Foundations of Democracy and the Rule of Law. American Political Science Review, 91(2), 245-263.

Wright, J. (2008). Do Authoritarian Institutions Constrain? How Legislatures Affect Economic Growth and Investment. American Journal of Political Science, 52(2), 322-343.

Wright, J., Frantz, E., \& Geddes, B. (2015). Oil and Autocratic Regime Survival. British Journal of Political Science, 45(2), 287-306.

Zorn, C. (2001). Estimating Between- And Within-Cluster Covariate Effects, with An Application To Models of International Disputes. International Interactions, 27, 433-445. 
Table 1: Coup Replacement Model

\begin{tabular}{|c|c|c|c|c|c|}
\hline & Model 1 & Model 2 & Model 3 & Model 4 & Model 5 \\
\hline \multicolumn{6}{|l|}{ DV:Coup Replacement } \\
\hline \multicolumn{6}{|l|}{ Independent Variables } \\
\hline \multirow[t]{2}{*}{ Coup Entry } & $-1.137 * *$ & $-1.157^{* *}$ & $-1.238 * *$ & $-1.581 * * *$ & $-1.676^{* * *}$ \\
\hline & $(.558)$ & $(.553)$ & $(.571)$ & $(.498)$ & $(.517)$ \\
\hline \multirow[t]{2}{*}{ Coup Entry $\times \log ($ Tenure $)$} & $.654 * *$ & $.689^{* * *}$ & $.715^{* * *}$ & $.842^{* * *}$ & $.872 * * *$ \\
\hline & $(.252)$ & $(.260)$ & $(.265)$ & $(.263)$ & $(.268)$ \\
\hline \multirow[t]{2}{*}{$\log$ (Tenure) } & -.265 & -.302 & -.296 & -.209 & -.202 \\
\hline & $(.204)$ & $(.211)$ & $(.211)$ & (.189) & $(.187)$ \\
\hline \multicolumn{6}{|l|}{ Control Variables } \\
\hline \multirow[t]{2}{*}{$\log (\mathrm{GDP} /$ capita $)$} & -.077 & -.032 & -.026 & -.104 & -.099 \\
\hline & $(.177)$ & $(.185)$ & $(.186)$ & $(.194)$ & (.196) \\
\hline \multirow[t]{2}{*}{ log(Military Budget) } & $-.111 * * *$ & $-.126 * * *$ & $-.133 * * *$ & $-.112 * *$ & $-.120 * *$ \\
\hline & $(.039)$ & $(.045)$ & $(.045)$ & $(.047)$ & $(.046)$ \\
\hline \multirow[t]{2}{*}{ Military Dictator } & -.022 & -.061 & -.059 & -.188 & -.188 \\
\hline & $(.361)$ & $(.365)$ & $(.367)$ & $(.387)$ & $(.390)$ \\
\hline \multirow[t]{2}{*}{ Monarch } & $-2.150 * * *$ & $-2.180^{* * *}$ & $-2.149 * * *$ & $-2.366^{* * *}$ & $-2.331 * * *$ \\
\hline & $(.719)$ & $(.729)$ & $(.722)$ & $(.737)$ & $(.731)$ \\
\hline \multirow[t]{2}{*}{ Party } & $-2.232 * * *$ & $-2.224 * * *$ & $-2.233 * * *$ & $-2.618 * * *$ & $-2.632 * * *$ \\
\hline & $(.510)$ & $(.509)$ & $(.513)$ & $(.404)$ & $(.409)$ \\
\hline \multirow[t]{2}{*}{ Failed Coup } & -.402 & -.434 & -.449 & -.545 & -.557 \\
\hline & $(.415)$ & $(.421)$ & $(.423)$ & $(.427)$ & $(.429)$ \\
\hline \multirow[t]{2}{*}{ Interstate War } & & -.073 & -.103 & -.053 & -.092 \\
\hline & & $(.762)$ & $(.775)$ & $(.837)$ & $(.852)$ \\
\hline \multirow[t]{2}{*}{ Change in $\log (\mathrm{GDP} /$ capita $)$} & & $-.027 * * *$ & $-.027 * * *$ & $-.028 * *$ & $-.027 * *$ \\
\hline & & $(.010)$ & $(.009)$ & (.010) & $(.011)$ \\
\hline \multirow[t]{2}{*}{ Purge } & & & .411 & & .472 \\
\hline & & & $(.329)$ & & $(.335)$ \\
\hline \multirow[t]{2}{*}{ Bolivia } & & & & $3.931 * * *$ & $3.974 * * *$ \\
\hline & & & & $(.455)$ & $(.466)$ \\
\hline \multirow[t]{2}{*}{ Constant } & .544 & .446 & .449 & .979 & .988 \\
\hline & $(1.259)$ & $(1.262)$ & $(1.273)$ & $(1.33)$ & ( 1.344$)$ \\
\hline $\mathrm{N}$ & 2805 & 2793 & 2793 & 2793 & 2793 \\
\hline Log Likelihood & -314.259 & -311.497 & -310.773 & -296.814 & -295.892 \\
\hline
\end{tabular}


Table 2: Coup Entry and Elite Elimination

\begin{tabular}{|c|c|c|c|c|}
\hline & Model 1 & Model 2 & Model 3 & Model 4 \\
\hline Model & \multicolumn{4}{|c|}{ Logit } \\
\hline Dependent Variable: & \multicolumn{2}{|c|}{ Purge I } & \multicolumn{2}{|c|}{ Purge II } \\
\hline \multicolumn{5}{|l|}{ Independent Variables } \\
\hline \multirow[t]{2}{*}{ Coup Entry } & $1.109 * * *$ & $1.081 * * *$ & $.879 * * *$ & $.852 * * *$ \\
\hline & $(.231)$ & $(.220)$ & $(.258)$ & $(.247)$ \\
\hline \multirow[t]{2}{*}{ Coup Entry $\times \log ($ Tenure $)$} & $-.415^{* * *}$ & $-.412 * * *$ & $-.362 * *$ & $-.360 * *$ \\
\hline & $(.136)$ & $(.134)$ & $(.140)$ & (.139) \\
\hline \multirow[t]{2}{*}{$\log ($ Tenure $)$} & .171 & .045 & $.256^{* *}$ & .141 \\
\hline & $(.136)$ & $(.171)$ & (.129) & $(.161)$ \\
\hline \multicolumn{5}{|l|}{ Control Variables } \\
\hline \multirow[t]{2}{*}{ Military Dictator } & .155 & .181 & .266 & .291 \\
\hline & $(.208)$ & $(.203)$ & $(.208)$ & $(.202)$ \\
\hline \multirow[t]{2}{*}{ Monarch } & $-1.007 * *$ & $-.928 *$ & $-1.00 * *$ & $-.926 * *$ \\
\hline & $(.460)$ & $(.478)$ & $(.443)$ & $(.460)$ \\
\hline \multirow[t]{2}{*}{ Party } & .034 & .040 & -.089 & -.085 \\
\hline & $(.221)$ & $(.218)$ & $(.226)$ & $(.223)$ \\
\hline \multirow[t]{2}{*}{ Failed Coup } & $.765 * * *$ & $.706^{* * *}$ & $.763 * * *$ & $.709^{* * *}$ \\
\hline & $(.165)$ & $(.163)$ & $(.166)$ & $(.165)$ \\
\hline \multirow[t]{2}{*}{ Interstate War } & $.628 * *$ & $.571^{*}$ & .530 & .474 \\
\hline & $(.301)$ & $(.298)$ & $(.366)$ & $(.364)$ \\
\hline \multirow[t]{2}{*}{$\log (\mathrm{GDP} /$ capita $)$} & $-.243 * * *$ & $-.235 * * *$ & $-.265^{* * * *}$ & $-.258 * * *$ \\
\hline & $(.083)$ & $(.083)$ & $(.082)$ & $(.082)$ \\
\hline \multirow[t]{2}{*}{$\log$ (Military Budget) } & $.211 * * *$ & $.198 * * *$ & $.213^{* * *}$ & $.201 * * *$ \\
\hline & $(.046)$ & $(.045)$ & $(.050)$ & (.049) \\
\hline \multirow[t]{2}{*}{ Number of Past Purges } & & $.095^{*}$ & & $.088^{*}$ \\
\hline & & $(.052)$ & & $(.051)$ \\
\hline \multirow[t]{2}{*}{ Years after Purges } & $-.163^{* * *}$ & -.123 & $-.151 * *$ & -.116 \\
\hline & $(.072)$ & $(.082)$ & $(.072)$ & $(.080)$ \\
\hline \multirow[t]{2}{*}{ Constant } & $-3.084 * * *$ & $-2.967 * * *$ & $-3.052 * * *$ & $-2.938 * * *$ \\
\hline & $(.698)$ & $(.687)$ & $(.721)$ & $(.709)$ \\
\hline$\overline{\mathrm{N}}$ & 2805 & 2805 & 2805 & 2805 \\
\hline Log Likelihood & -849.746 & -848.433 & -821.974 & -820.829 \\
\hline
\end{tabular}


Table 3: Coup Replacement and Elite Elimination Model

\begin{tabular}{|c|c|c|c|c|}
\hline & Model 1 & Model 2 & Model 3 & Model 4 \\
\hline Model & \multicolumn{2}{|c|}{ Logit } & \multicolumn{2}{|c|}{ Ordered Logit } \\
\hline Dependent Variable: & \multicolumn{2}{|c|}{ Purge I } & \multicolumn{2}{|c|}{ Purge I Level } \\
\hline Measurement Model in Table 1: & Model 1 & Model 2 & Model 1 & Model 2 \\
\hline \multicolumn{5}{|l|}{ Independent Variable } \\
\hline $\operatorname{Pr}(\text { Coup Replacement })_{D e v}$ & $\begin{array}{r}-10.401 * * \\
(4.230)\end{array}$ & $\begin{array}{c}-7.624 * * \\
(3.646)\end{array}$ & $\begin{array}{r}-9.239 * * \\
(4.067)\end{array}$ & $\begin{array}{l}-6.588^{* *} \\
(3.259)\end{array}$ \\
\hline \multicolumn{5}{|l|}{ Controls } \\
\hline Military Dictator & $\begin{array}{l}.378 * * \\
(.158)\end{array}$ & $\begin{array}{l}.377 * * * \\
(.144)\end{array}$ & $\begin{array}{l}.382 * * * \\
(.133)\end{array}$ & $\begin{array}{l}.382 * * \\
(.160)\end{array}$ \\
\hline Monarch & $\begin{array}{c}-1.648 * * \\
(.692)\end{array}$ & $\begin{array}{c}-1.445^{* *} \\
(.688)\end{array}$ & $\begin{array}{c}-1.625^{* * *} \\
(.702)\end{array}$ & $\begin{array}{c}-1.435^{* *} \\
(.631)\end{array}$ \\
\hline Party & $\begin{array}{c}-1.119 * * \\
(.466)\end{array}$ & $\begin{array}{l}-.883^{*} \\
(.477)\end{array}$ & $\begin{array}{l}-.998 * * \\
(.502)\end{array}$ & $\begin{array}{l}-.775^{*} \\
(.445)\end{array}$ \\
\hline Interstate War & $\begin{array}{r}.811^{* * * *} \\
(.279)\end{array}$ & $\begin{array}{l}.790 * * \\
(.314)\end{array}$ & $\begin{array}{l}.859 * * * \\
(.317)\end{array}$ & $\begin{array}{l}.836 * * * \\
(.272)\end{array}$ \\
\hline $\log (\mathrm{GDP} /$ capita $)$ & $\begin{array}{c}-.200 * * * \\
(.060)\end{array}$ & $\begin{array}{c}-.192 * * * \\
(.062)\end{array}$ & $\begin{array}{r}-.171 * * \\
(.085)\end{array}$ & $\begin{array}{l}-.164 * * \\
(.065)\end{array}$ \\
\hline $\operatorname{Pr}(\text { Coup Replacement })_{\text {Med }}$ & $\begin{array}{r}-13.246 * * \\
(6.142)\end{array}$ & $\begin{array}{c}-12.377^{*} \\
(6.756)\end{array}$ & $\begin{array}{r}-11.715^{* *} \\
(5.919)\end{array}$ & $\begin{array}{c}-11.128^{* * *} \\
(5.319)\end{array}$ \\
\hline Years after Purges & $\begin{array}{c}-.196^{* * *} \\
(.053)\end{array}$ & $\begin{array}{c}-.203 * * * \\
(.056)\end{array}$ & $\begin{array}{c}-.208 * * * * \\
(.051)\end{array}$ & $\begin{array}{c}-.216 * * * \\
(.053)\end{array}$ \\
\hline Constant & $\begin{array}{l}1.091 \\
(.799)\end{array}$ & $\begin{array}{c}.796 \\
(.743) \\
\end{array}$ & & \\
\hline Odds Ratio & & & & \\
\hline $\operatorname{Pr}(\text { Coup Replacement })_{D e v}$ & & & .0001 & .0014 \\
\hline Cut Point 1 & & & -.682 & -.414 \\
\hline Cut Point 2 & & & -.652 & -.385 \\
\hline Cut Point 3 & & & -.201 & .066 \\
\hline Cut Points $1=$ Cut Point $2 ?$ & & & 0.0108 & 0.0121 \\
\hline Cut Points 2 = Cut Point 3 ? & & & 0.0000 & 0.0000 \\
\hline $\mathrm{N}$ & 2805 & 2793 & 2791 & 2779 \\
\hline Log Likelihood & -880.005 & -879.374 & -1055.710 & -1054.9811 \\
\hline
\end{tabular}

